九州大学学術情報リポジトリ

Kyushu University Institutional Repository

Lasioglossum (Evylaeus) tadauchi i sp. nov. (Hymenoptera, Halictidae) from Amami-Ôshima, southwestern Japan

Murao, Ryuki

Entomological Laboratory, Faculty of Agriculture, Kyushu University

https://doi.org/10.5109/25401

出版情報 : ESAKIA. 52，pp.91-94，2012-03-27. Entomological Laboratory，Faculty of Agriculture， Kyushu University

バージョン :

権利関係 : 


\title{
Lasioglossum (Evylaeus) tadauchii sp. nov. (Hymenoptera, Halictidae) from Amami-Ôshima, Southwestern Japan
}

\author{
Ryuki Murao \\ Entomological Laboratory, Faculty of Agriculture, Kyushu University, Fukuoka, 812-8581 Japan
}

\begin{abstract}
Lasioglossum (Evylaeus) tadauchii sp. nov. is described and illustrated based on female specimens collected from Amami-Ôshima, the central Ryukyus, southwestern Japan. This new species to the sexstrigatum species group in the carinaless Evylaeus. A modified key to the carinaless Evylaeus species occurring in the central and southern Ryukyus is provided, as well as data on some bionomical notes of this new species.
\end{abstract}

Key words: taxonomy, Hymenoptera, Halictidae, Lasioglossum, Evylaeus, new species, Japan, Ryukyus.

\section{Introduction}

The subgenus Evylaeus Robertson (sensu Ebmer, 2002; Pesenko, 2007) of Lasioglossum (Halictidae) contains approximately 400 species worldwide (Pesenko, 2007). Fifty-eight species have so far been recorded from Japan until now. Recently, I had an opportunity to examine some specimens of Lasioglossum collected in AmamiÔshima which is situated approximately $300 \mathrm{~km}$ north of Okinawa-jima and $380 \mathrm{~km}$ south of Kyushu. After careful examination, I found a new species belonging to the subgenus Evylaeus in the material. In the present paper, I describe the new species with some bionomical notes.

This study is based on specimens deposited in the following institutions, which are referred to in the text by the following abbreviations: ELKU, Entomological Laboratory, Faculty of Agriculture, Kyushu University, Fukuoka Pref., Japan; MNHAH, the late Dr. Shôichi F. Sakagami's Collection, Museum of Nature and Human Activities, Hyogo Pref., Sanda, Japan; and without acronym, my private collection, now deposited in the ELKU. Terminology and style used in the description follow Murao and Tadauchi (2007). Abbreviations used in the text are as follows: Fn = nth antennal flagellomere; IS = interspaces between punctures; $\mathrm{PP}=$ punctures; $\mathrm{Sn}=$ nth metasomal sternum; $\mathrm{Tn}=\mathrm{nth}$ metasomal tergum. The scientific names of flowering plants visited by bees are cited from Yonekura \& Kajita (2003).
I dedicate this paper with gratitude to Prof. Osamu Tadauchi on his retirement from Kyushu University. I would like to express my sincere thanks to him and Dr. Layne Julian Westover (Kyushu University) for their critical reading of an early draft. I also express thanks to Mr. P. Andreas Werner Ebmer (Austria) for his support in this study and Dr. Katsushi Mitai (Kyushu University) for providing valuable specimens. This research was supported by the Environment Research and Technology Development Fund (S-9-2(8)) of the Ministry of the Environment. This is a contribution from the Entomological Laboratory, Faculty of Agriculture, Kyushu University, Fukuoka (Ser. 6, No. 109).

\section{Lasioglossum (Evylaeus) tadauchii Murao sp. nov.}

(Figs. 1-14)

Diagnosis. This species belongs to the sexstrigatum group in the carinaless Evylaeus, mainly in having the following combination of morphological characters: head broad; propodeal dorsum relatively short, without transverse carina on boarder between dorsal and vertical surfaces; vertical surface of propodeum without lateral carina on upper half; metasomal terga with distinct fimbriae lateroapically. Within the sexstrigatum group, this species is similar to Lasioglossum (Evylaeus) taeniolellum (Vachal, 1903) from Japan proper and L. (E.) perplexans (Cockerell, 
1925) from Russian Far East. However, it is separated from the former by the postgena having distinct lineolation over its entire surface, the distal process of labrum without lateral projection, and the T1 with short hairs and fine PP on disc; from the latter by the propodeal dorsum with short longitudinal ridges on basal half. In contrast, in L. (E.) taeniolellum the lineolation on postgena does not attain to the apical margin, the distal process of labrum with horn-like lateral projection, and T1 smooth; in $L$. (E.) perplexans, the ridges on propodeal dorsum attaining to apical margin.

Description. Female. Body length 5.4-5.8mm, wing length 4.5-5.0mm $(\mathrm{n}=5)$.
Color. Body black except on the following parts: mandible reddish brown apically; flagellum brown or blackish brown ventrally; tegula yellowish brown translucent; wings nearly transparent; veins and pterostigma brown or blackish brown; tibial spur yellow; metasomal terga apically broadly yellowish brown translucent.

Pilosity. Body hairs nearly whitish. Head with sparse fine branched hairs excluding clypeus with sparse simple and short hairs. Hairs on mesosoma finely branched except on the following parts: tomentum around pronotal lobe and propodeal side, whitish, moderately dense; hind femur with plumose hairs, forming scopa. T1 (Fig. 7) basally with sparse fine branched hairs, medially with moderately

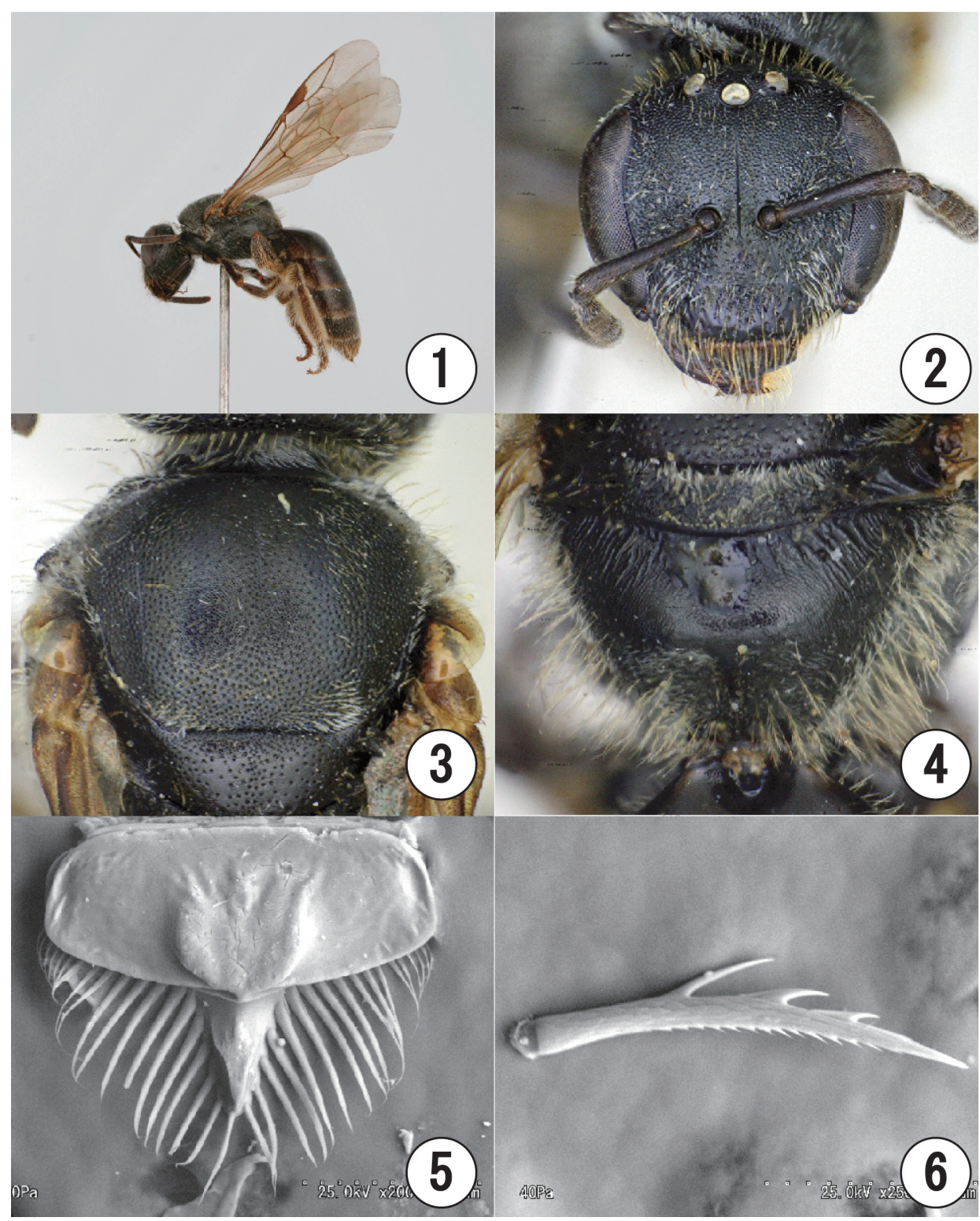

Figs. 1-6. Lasioglossum (Evylaeus) tadauchii Murao, sp. nov. 1-4, holotype. 5, 6, paratype. 1, lateral habitus. 2, head in frontal view. 3, mesoscutum. 4, propodeal dorsum. 5, labrum. 6, inner hind tibial spur. 
dense simple and short hairs. T2-T4 with moderately dense simple and short hairs on disc. T5 with moderately dense fine branched hairs. Metasomal terga without distinct basal hair bands, with apical fimbriae on T2-T4, T2T3, or T3-T4 (T2-T4 in holotype).

Structure. Head wider than long; head length/width ratio $0.89-0.93(n=8)$. Vertex round on top, weakly rugulae behind posterior ocelli. Interocellar distance nearly as long as ocellocular distance, and 0.8-0.9 times ocelloocipital distance. Frons and paraocular area dull, reticulate-punctate over entire surface. Supraclypeal area nearly flat, dull, with moderately dense PP; IS with distinct tessellation. Clypeal length 1.1-1.3 times distance between lower rim of antennal socket and upper margin of clypeus; nearly flat, shiny on upper half, dull on lower half, with sparse PP over entire surface (shallow PP on lower half); IS with distinct tessellation on upper half, nearly smooth on lower half. Basal area of labrum 2.3 times as wide as long; basal elevation moderately developed; lateral projection of distal process absent; keel of distal process broad, pointed apically in frontal view; labral fimbria acutely pointed at apex. Mandible bidentate. Hypostomal carina weakly developed; its anterior angle obtuse. Postgena with distinct longitudinal lineolation over entire surface. Scape length $0.6-0.7 \mathrm{~mm}(\mathrm{n}=8), \mathrm{F} 1$ length as long as F2.

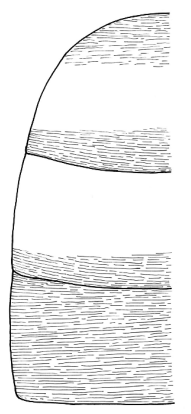

8
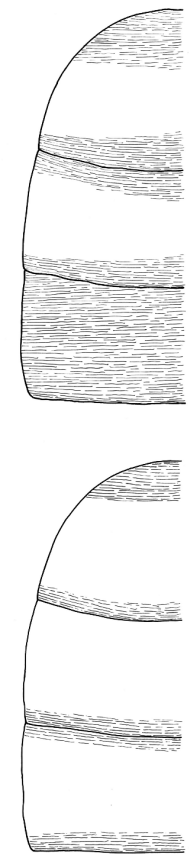

7

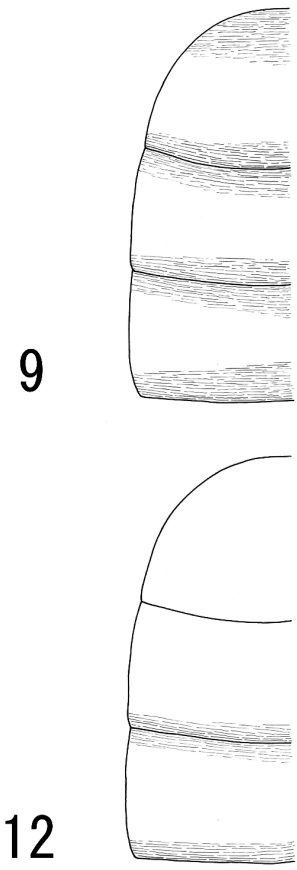

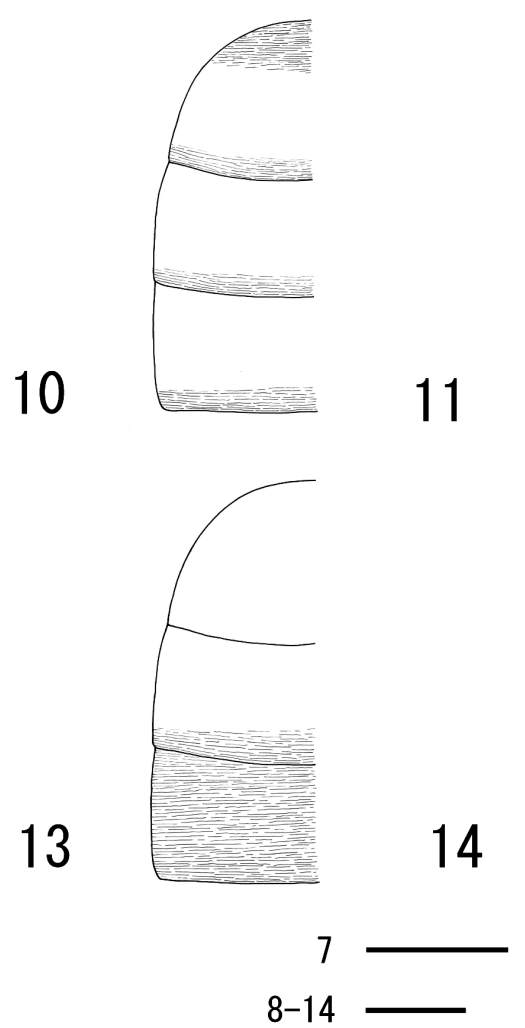

Figs. 7-14. Lasioglossum (Evylaeus) tadauchii Murao, sp. nov. 7, 8, holotype. 9-14, paratypes. 7, first metasomal tergum. 8-14, variation of lineolation on first to third metasomal terga. Scale bars, $0.5 \mathrm{~mm}$. 
Pronotal dorsolateral angle obtuse, not projecting; lateral ridge absent; lateral sulcus shallow. Mesoscutum (Fig. 3) dull, with dense PP and IS with distinct tessellation over entire surface. Mesoscutellum weakly shiny, marginally and longitudinally with moderately dense PP; IS weakly tessellate over entire surface. Metanotum weakly rugulose over entire surface. Mesepisternum dull, reticulate-punctate and weakly tessellate over entire surface. Metepisternum with distinct transverse ridges on upper half. Propodeal dorsum (Fig. 4) weakly shiny, 0.8-0.9 times mesoscutellum, and 1.3-1.6 times metanotum; dorsomedially with longitudinal ridges on basal half, and with distinct tessellation on apical half; transverse carina absent; propodeal side weakly rugulose; shield distinctly tessellate over entire surface. Inner hind tibial spur (Fig. 6) with 2-4 slender teeth $(\mathrm{n}=8)$.

Metasomal terga shiny. T1 medially with moderately dense fine PP. T2 with moderately dense fine PP on basal half. T4 with weak lineolation over entire surface.

Male. Unknown.

Variation. The lineolate variation on T1-T3 shown as in Figs. 8-14. In the holotype (Fig. 8), the lineolation on $\mathrm{T} 1$ basally and apically, T2 only apically, and T3 over entire surface.

Distribution. Japan (central Ryukyus: Amami-Ôshima).

Flight record. Female: April to October.

Flower record. The flowering plants visited by this species were two species in two families as follows: Eupatorium variabile (Asteraceae) and Fallopia japonica var. japonica (Polygonaceae).

Collecting site. So far as the author's surveyed in Amami-Ôshima, this species was collected only from around subtropical forests at mountain areas. Unlike the other congeners, it may prefer humid environments for its habitat.

Etymology. The name of this new species is dedicated to Prof. Osamu Tadauchi of the Entomological Laboratory of Kyushu University, who supported my study in many ways.

Type series. Holotype (Type No. ELKU 3316): female, Nishinakama, Amami-Ôshima, Kagoshima Pref., Ryukyus, Japan, 24. v. 1973 (H. Makihara, ELKU). Paratypes: [Ryukyus] [JAPAN] Amami-Ôshima, Kagoshima Pref.: 1 female, Mt. Yui-dake, Setouchi-cho, Ôshima-gun, 6. iv. 2005 (K. Mitai); 2 females, Mt.
Yuwan-dake, Uken-son, 14. x. 2004 (R. Murao); 2 females, Santarou-toge, Sumiyo-son, 15. x. 2004 (R. Murao); 1 female, Shin-mura Nishinakama, 3. x. 1971 (H. Fukuda, MNHAH); 1 female, Shinokawa, 15. v. 1953 (T. Shiraki, ELKU).

Type depository. The holotype and six paratypes are deposited in ELKU, the one paratype in MNHAH.

\section{Modified key to the carinaless Evylaeus species in the central and southern Ryukyus, Japan}

A modified key to species of the carinaless Evylaeus occurring in the central and southern Ryukyus is presented based on a key provided by Murao et al. (2010, page 31). In their key, Lasioglossum (Evylaeus) tadauchii sp. nov. will run to couplet 2 as presented below.

\section{Females}

1. Metasomal terga with distinct apical fimbriae ......... 2'

- Metasomal terga without apical fimbriae .................... 3

2'. T1 medially with distinct fine PP and short hairs

.... Lasioglossum (Evylaeus) tadauchii Murao sp. nov.

- T1 medially without PP and short hairs 2

2. T1 smooth or only basally with weak lineolation L. (E.) amamiense Ebmer et Sakagami

- T1 with distinct lineolation on the entire surface L. (E.) smilodon Ebmer et Sakagami

\section{References}

Ebmer, A. W., 2002. Asiatische Halictidae-10. Neue Halictidae aus China sowie diagnostische Neubeschriebungen der von Fan \& Ebmer 1992 beschriebenen Lasioglossum-Arten (Insecta: Hymenoptera: Apoidea: Halictidae: Halictinae). Linz. biol. Beitr., 34: 819-934.

Murao, R. \& O. Tadauchi, 2007. A revision of the subgenus Evylaeus of the genus Lasioglossum in Japan (Hymenoptera, Halictidae) Part I. Esakia, (47): 169-254.

Murao, R., O. Tadauchi, M. Goubara \& Y. Maeta, 2010. Taxonomy of the carinaless group of Lasioglossum (Evylaeus) (Hymenoptera, Halictidae) from the Ryukyu Islands, Japan, with description of seven new species. Zootaxa, 2669: 1-33.

Pesenko, Yu. A., 2007. Subgeneric classification of the Palaearctic bees of the genus Evylaeus Robertson (Hymenoptera: Halictidae). Zootaxa, 1500: 1-54.

Yonekura, K. \& T. Kajita, 2003. BG Plants Japanese-scientific names index (Ylist). http://bean.bio.chiba-u.ac.jp/bgplants/ ylist_main.html (finally accessed on 9 September 2011). 